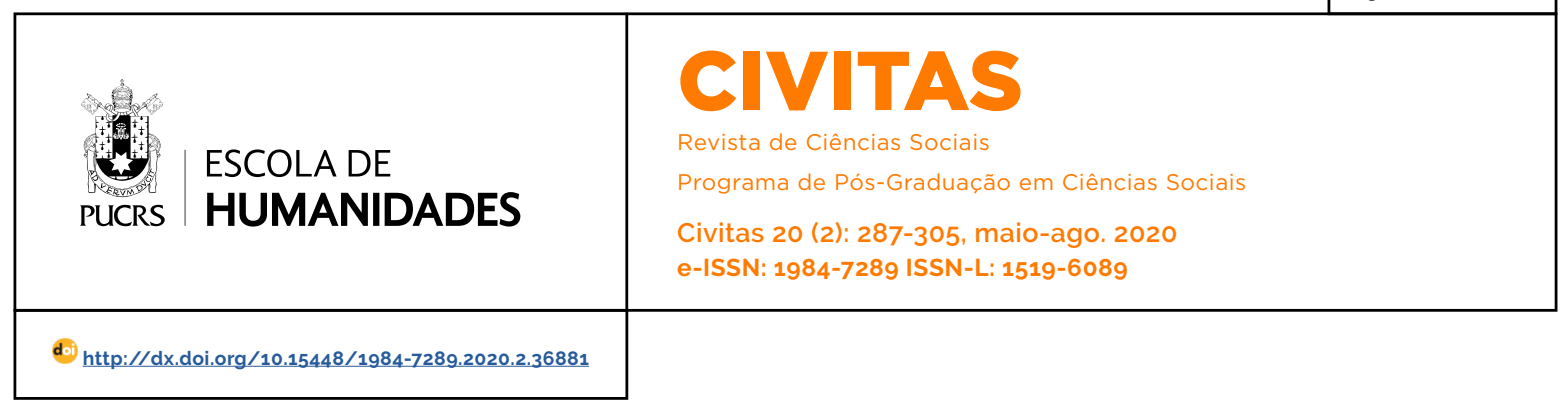

DOCUMENTO/DOCUMENT

\title{
Georg Rusche: um ensaio biográfico
}

\author{
Georg Rusche: a biographical essay \\ Georg Rusche: un ensayo biográfico
}

\section{Dario Melossi ${ }^{1}$}

orcid.org/0000-0002-3058-8701

dario.melossi@unibo.it

Recebido em: 19 nov. 2019.

Aprovado em: 17 jan. 2020.

Publicado em: 4 ago. 2020

\section{(c) (1)}

Artigo está licenciado sob forma de uma licença Creative Commons Atribuição 4.0 Internacional.

\section{Apresentação da tradução²}

O livro Punição e estrutura social, de autoria de Georg Rusche e Otto Kirchheimer, publicado originalmente em inglês em 1939 e reeditado em 1968, foi, e ainda é, de grande relevância para os estudos das ciências sociais e da criminologia, ao menos desde a década de 1970, quando acontece a chamada "virada criminológica" nos estudos sobre a punição e o crime.

A recuperação do livro a partir dos anos 1970, por um lado, se deve ao fato de ter se tornado uma referência para os estudos da assim chamada criminologia critica, que buscou analisar os fenômenos criminais a partir de uma perspectiva marxista. Por outro lado, Michel Foucault $(1975,27)$, em seu influente e polêmico livro, Vigiar e punir, citou o "grande livro" de Rusche e Kirchheimer como referência para uma análise que buscava entender os sistemas punitivos como fenômenos sociais e os efeitos positivos e úteis das medidas punitivas.

Essa dupla revalorização tornou o livro uma referência para os trabalhos críticos que passaram a observar os fenômenos punitivos e criminais sob uma ótica multidimensional e não exclusivamente a partir da ótica juridica ou mesmo institucional. Diante do "giro punitivo" do final do século 20 ou do avanço do "encarceramento em massa", a perspectiva dos autores de estabelecer "a relação entre os vários sistemas punitivos e os sistemas de produção em que se efetuam" (Foucault 1977, 27) passou a ser considerada fundamental para recolocar o crime e a punição como parte constitutiva da vida social.

Contudo, apesar de suas múltiplas utilizações e referências desde então, sabe-se muito pouco sobre a história e o contexto de produção e de finalização do livro, considerando que um de seus autores - Georg Rusche - morreu no início da década de 1950 e as informações que constam das apresentações do livro original e de suas traduções, inclusive no Brasil, não dão conta de informações relevantes e do caminho tortuoso que levou à sua forma final.

\footnotetext{
Universidade de Bologna, Bologna, Itália.

Originalmente esse texto foi publicado em 1980 com o título Georg Rusche: a biographical essay. Crime and Social Justice 14, focus on racism (Winter 1980): 51-63. https://Www.jstor.org/stable/29766101. Traduzido do inglês e aqui apresentado por Mariana Chies Santiago Santos socióloga e advogada, pesquisadora de pós-doutorado no Núcleo de Estudos da Violência da Universidade de São Paulo (NEV-USP). Revisão do professor livre-docente Marcos César Alvarez, do departamento de Sociologia, FFLCH, USP. Agradecemos especialmente à Emília Merlini Giuliani pela revisão dos termos em alemão e pelas explicações que foram dadas para a melhor tradução do texto.
} 
O presente artigo traduzido, publicado originalmente em inglês, em 1980, de autoria de Dario Melossi, professor da Universidade de Bologna (Bologna, Itália) e da Universidade de Califórnia (Berkeley, EUA), mostra-se extremamente importante para esclarecer os conceitos básicos e originais do pensamento de Georg Rusche, que acabaram em grande medida distorcidos pelas desventuras do Instituto de Pesquisa Social no exílio e pelo périplo trágico do autor. Além do interesse em termos da história intelectual e da política da assim chamada Escola de Frankfurt, dos estudos de criminologia e de sociologia da punição, são os traços da personalidade intelectual de Georg Rusche que se mostram vagamente a partir da investigação realizada. Melossi, eminente criminólogo italiano, recupera aspectos da personalidade de Rusche, infelizmente destruida e esquecida em meio à violência da guerra e às armadilhas burocráticas e pessoais. ${ }^{3}$ Em contato com o professor Dario Melossi e com o editor original do texto, houve a autorização para a sua tradução e consequente publicação no Brasil. ${ }^{4}$

\section{Introdução}

O presente artigo é o resultado de uma pesquisa que conduzi entre 1977 e 1980 na Inglaterra, na Alemanha e nos Estados Unidos (EUA), que tem por objeto a reconstrução da vida de Georg Rusche. É o primeiro esforço para lidar com esse tema, e os materiais aqui apresentados, ao menos pelo que consta da documentação, nunca foram publicados. Primeiramente, é um tributo à memória de um homem, cujas ideias assumiram um papel cada vez mais central, nos recentes anos, após um esforço da "criminologia crítica" de se alinhar de forma mais sofisticada com perspectivas teóricas da macrossociologia e das comparações históricas. A descoberta do trabalho principal de Rusche, reelaborado por Otto Kirchheimer, Punição e estrutura social, veio a representar um passo decisivo nessa direção.
Em segundo lugar, uma compreensão mais completa da vida de Rusche e o processo intelectual de produção de seu principal trabalho, como se espera aqui, provavelmente lançará nova luz sobre seu conteúdo substantivo.

Ao mesmo tempo, contudo, esse ensaio não tem a pretensão nem de discutir o trabalho de Rusche nem, tampouco, de fazer uma avaliação das suas contribuições teóricas para as questões criminais e penais. Isso foi o que tentei fazer no ensaio introdutório à nova versão de Punição e estrutura social, publicado em Crime and social justice dois anos atrás (Melossi 1978). O presente ensaio biográfico adiciona alguns materiais e pode ser visto como marginalmente inovador vis-à-vis meu artigo de 1978, mas, ao fim e ao cabo, o presente artigo não passa de uma conclusão desse último e isso deve ser lembrado pelo leitor.

Muitas áreas ainda precisam ser exploradas em relação à vida de Georg Rusche. Elas vão desde as relações "tensas" que ele mantinha com alguns de seus colaboradores - especialmente com o círculo da Escola de Frankfurt, cujos documentos e na própria memória de seus membros qualquer referência à existência de Rusche parece ter desaparecido por completo após contatos iniciais na Alemanha pré-nazista - até o destino trágico que parece ter acompanhado sua existência, com sua fuga da Alemanha após a tomada do poder pelos nazistas em 1933, até sua morte autoinfligida, em Londres, em 1950. O esquecimento quase completo do trabalho de Rusche e sua desilusão progressiva provavelmente nunca serão totalmente compreendidos. Parece justo que agora, em adição ao conhecimento sobre seu trabalho, possamos garantir um conhecimento básico de sua vida, entre limites e ambiguidades, com certeza, que são determinados pelas documentações arquivadas e pelos testemunhos dos poucos que o conheceram e que estão dispostos a prestar tributo às suas memórias.

\footnotetext{
3 Dario Melossi é coautor, com Massimo Pavarini lin memoriaml, do livro Cárcere e fábrica e autor de diversos artigos sobre "questões penais". No momento da escrita deste artigo, estava escrevendo sua tese de doutoramento em Sociologia na Universidade da Califórnia, Santa Bárbara, EUA.

4 Agradecemos aos/às editores/as da revista Social Justice: a journal of crime, conflict \& world order pela permissão da tradução e publicação do presente artigo. http://www.socialjusticejournal.org.
} 


\section{Anos de formação}

Georg Rusche nasceu em Hannover, em 17 de novembro de 1900, de - como ele mesmo descreve - um "casamento misto na Alemanha Imperial" (Rusche 1941). Seu pai era Dr. Georg Rusche, médico, de Hagen, Renânia do Norte-Vestefália. Sua ascendência judaica era de sua mãe, que parece ter tido relação de parentesco com os mais altos escalões políticos alemães. De fato, tanto nos arquivos de Rusche na Society for Protection of Science and Learning, de Londres (Arquivo da Sociedade, a seguir designado SPSL 1) 5 quanto de minha conversa com Hannah $\mathrm{H}$. Striesow, ${ }^{6}$ uma conhecida próxima de Rusche em Londres na década de 1940, Rusche parece ser um sobrinho do - ou ter algum grau de parentesco com - eminente estadista de Weimar, Gustav Stresemann e, segundo Striesow, também estaria de alguma forma ligado à poderosa dinastia politico-industrial da familia Rathenau. Consequentemente, Rusche era "não ariano" (SPSL I) mas, ao mesmo tempo, ele próprio não estava comprometido com suas raízes semijudaicas, uma falta de sentimento que não era raro nas famílias judias da classe alta da época. ${ }^{7}$ Mais tarde, após a tomada do poder nazista na Alemanha, esse status passou a dominar sua vida.

Ele recebeu uma educação típica de famílias alemãs abastadas. Depois de passar a juventude na casa de seus pais, onde recebeu sua educação básica, frequentou o Humanistische Gymnasium ${ }^{8}$ em Hagen e, depois, passou um curto periodo de instrução militar no Corpo de Cadetes. ${ }^{9}$ Após a Primeira Guerra Mundial, na qual Rusche provavelmente era jovem demais para lutar, ele dedicou a maior parte da década de 1920 aos estudos universitários na Alemanha do pós-guerra.
Ele estudou filosofia, direito e ciências sociais em algumas das melhores universidades alemãs - Münster, Frankfurt, Göttingen e Colônia ${ }^{10}$ - e no exterior, em Paris e Londres. Ele obteve seu doutorado na Universidade de Colônia, mas Göttingen e mais tarde Frankfurt também parecem terem sido centrais na sua formação intelectual. Dos três estudiosos indicados por Rusche como seus mentores (Hauptsächlichsten Lehrer), dois, o famoso filósofo e sociólogo Max Scheler e o economista Erwin v. Beckerath, estavam ensinando em Colônia e o terceiro, o filósofo Leonard Nelson, ensinava em Göttingen. Em Colônia, o Instituto de Pesquisa em Ciências Sociais acabara de ser fundado, sob a direção de Leopold v. Wiese, decano dos sociólogos alemães, e Christian Eckert, Max Scheler e Hugo Lindemann. Foi impossivel encontrar, no entanto, qualquer evidência ligando Rusche ao instituto recém-fundado, exceto por sua referência a Max Scheler, uma referência que, dada a fama do homem, poderia ter sido apenas uma questão de reputação.

Em vez disso, a conexão de Rusche com Nelson parece ter sido muito mais importante. Muitos anos depois, na década de 1940, após abandonar todo tipo de trabalho científico, Rusche ainda conseguia encontrar palavras de grande estima e admiração por Nelson (e somente por ele). ${ }^{11}$ Foi sob a direção de Leonard Nelson que Rusche escreveu sua tese de doutorado em filosofia em 1924, que the rendeu um título de doutor nessa disciplina; e, provavelmente, o segundo também, em economia e ciências sociais, que the concedeu um título de doutor em 1929, foi escrito sob a supervisão de Nelson. Possivelmente foi apenas devido à morte de Nelson, em 1927, que o supervisor formal ${ }^{12}$ para essa segunda tese fora

\footnotetext{
Society for the Protection of Science and Learning. I Rusche's file. London: Archive of the Society

Conversa com Hannah H. Striesow, Londres, 10 de janeiro de 1979.

Conversa do autor com Philip Urbach, Londres, 9 de janeiro de 1979

Nota da tradutora (NT): nome da escola que ele estudou a partir do ensino fundamental.

Conversa do autor com Philip Urbach, Londres, 9 de janeiro de 1979.

Optamos por deixar o nome de algumas das cidades em alemão para facilitar a leitura.

Conversa do autor com Philip Urbach, Londres, 9 de janeiro de 1979.

NT: Na Alemanha - nos casos em que o procedimento formal de avaliação de teses adotado pela faculdade é a Disputatio - o orientador de doutorado é normalmente também o primeiro avaliador (parecerista) da tese. Para receber o título de doutor/a, o/a candidato/a deve elaborar uma tese, que passará, em uma primeira fase, pela avaliação de dois pareceristas. O primeiro é, via de regra, o orientador e o segundo é outro professor da área. Só após a avaliação dos pareceristas é que ocorre a avaliação oral do/a candidato/a (banca de defesa). Como o orientador de Rusche faleceu antes que ele houvesse submetido sua tese a avaliação, quem acabou por assumir o papel de avaliador ou parecerista principal do trabalho foi v. [von] Beckerath, sendo possível que ele não tenha chegado a atuar como orientador de Rusche.
} 
o economista Erwin v. Beckerath (um especialista, principalmente, em transportes e comunicação).

Leonard Nelson (1882-1927) foi o fundador de uma das muitas escolas neokantianas da época, mais precisamente, a da Escola de Göttingen, universidade onde lecionou ao longo de sua vida. Essa escola também foi chamada de neofriesiana porque a filosofia de Nelson estava enraizada na redescoberta do filósofo kantiano do início do século XIX, Jakob Friedrich Fries (1773-1843). Fries era famoso por ser o porta-voz dos radicais Burschenschaften ${ }^{13}$ da juventude alemã da época e pelo ataque de Hegel contra ele no Prefácio de sua Filosofia do Direito, no qual criticou severamente Fries como o representante daqueles que desejavam substituir o "sentimento" da "comunidade" pela razão, ao lidar com questões políticas e com o estado (Marcuse 1955, 178; Specht e Eichler 1953).

A partir da crítica epistemológica de Kant e da filosofia kantiana de Fries, Nelson desenvolveu uma teoria política e do direito própria, que levou Struve a localizá-lo entre os "liberais em busca da elite" (Struve 1973, 186-215), na companhia digna de F. Naumann, M. Weber e W. Rathenau. O ideal da estrita adesão ao estado de direito, do Rechtsstaat, ${ }^{14}$ estava ligado a um princípio de justiça superior à racionalidade formal da lei, justiça que só poderia ser encarada por uma elite iluminada. Na economia, suas opiniões eram próximas das de seu amigo, o economista Franz Oppenheimer, um defensor do "socialismo liberal" - que na verdade significava uma confiança substancial na ideia de livre mercado, corrigida pela necessidade de intervenção do estado direcionada a uma função antimonopolista (Link 1964, 3-38; Schumpeter 1963, 854-855). Tradicionalmente liberal em sua teoria, o radicalismo de Nelson em tópicos específicos o colocou em contato com a esquerda social-democrata no período pós-guerra. Ele foi o fundador de duas organizações políticas de juventude de classe média na década de 1920 que, em vários momentos, se fundiram e colidiram com as várias organizações social-democratas. Nelson recebeu uma profunda devoção por parte de seu limitado número de seguidores. Rusche não parece ter sido um desses, pois o seu nome não está listado entre os seguidores de Nelson no livro de Link (1964), dedicado ao estudo das organizações de Nelson.

Ambas as teses de Rusche parecem ter a marca da influência de Nelson. O primeiro, em filosofia do direito e intitulado Bemerkungen zum Rechtsbegriff und zu den Grundsätzen der philosophischen Rechtslehre (Observações sobre o conceito de direito e os princípios da doutrina jurídica filosófica), ${ }^{15}$ investiga os fundamentos filosóficos da doutrina jurídica decorrente da filosofia do direito de Fries e Nelson (Rusche 1924). A segunda tese, em economia e ciências sociais, intitulada Bemerkungen zur logischen Grundlage der theoretischen Ökonomik: Eine Untersuchung über den Begriff der Wirtschaft und die Grundsätze der Wirtschaftswissenschaft (Observações sobre os fundamentos lógicos da teoria econômica: um estudo sobre o conceito de economia e os principios da economia), também está relacionada com a filosofia social e política de Nelson.

Esse sólido treinamento teórico e filosófico formou o pano de fundo de suas experiências em "prisão e trabalho social", no momento em que Rusche se tornou vice-diretor da prisão de Bautzen, perto de Leipzig, na Saxônia (Rusche 1941; SPSL I). ${ }^{16}$ Depois de sua experiência com administração penitenciária, Rusche aceitou o cargo de assistente no seminário de economia política da Universidade de Frankfurt, sob a direção de Karl Pribram, onde presumivelmente permaneceu até sua emigração da Alemanha em 1933. Há razões para pensar que a conexão com Pribram também teve uma influência notável na formação de Rusche. Profundamente instruido em filosofia, ciências sociais e, especialmente,

\footnotetext{
13 NT: Um tipo de associação de estudantes.

14 NT: Rechtsstaat significa, literalmente, estado de direito.

NT: Quando o autor traduziu o termo original do alemão para o inglês, nós optamos por traduzir também. No caso de somente estar em alemão no texto original, optamos por traduzir em nota de rodapé.

16 Também reportado na conversa do autor com Philip Urbach, Londres, 9 de janeiro de 1979.
} 
economia, Pribram ensinou na Universidade de Viena como um Privatdozent ${ }^{17}$ durante o período de 1911 a 1921, quando foi então nomeado chefe da Seção Estatística, Divisão de Pesquisa, do Escritório Internacional do Trabalho em Genebra, Suiça e, finalmente, ocupou o cargo de professor de economia e ciência política na Universidade de Frankfurt de 1928 a 1933, após o qual emigrou para os Estados Unidos. Em 1912, Pribram escreveu um tratado sobre filosofia social, Die Entstehung der individualistischen Sozialphilosophie (A origem da filosofia social individualista), na qual fez uso considerável de material da história do direito penal e examinou o desenvolvimento do "princípio individualista", da Idade Média à economia liberal clássica do século 18. Em Punição e estrutura social, esse trabalho de Pribram é citado na discussão de politicas demográficas no mercantilismo (Rusche e Kirchheimer 1939, 28). ${ }^{18}$ Então, na década de 1920 e por muito tempo depois, Pribram se dedicou ao estudo dos problemas trabalhistas, especialmente aqueles que lidavam com a questão do desemprego, pelos quais se tornou reconhecido internacionalmente (Pribram 1931; 1935; 1949).

É sob esse conjunto de influências - o liberalismo progressista e a teoria juridica de Nelson, as experiências pessoais de Rusche na prisão e no serviço social e a atenção de Pribram às questões do mercado de trabalho e do desemprego - que a tese principal de Rusche sobre "punição e mercado de trabalho" tomou forma. Em 1930, ele publicou um artigo sobre as revoltas nas prisões ocorridas na época nos Estados Unidos, ligando-as à situação social causada pela Depressão. ${ }^{19}$ Esse texto apareceu no Frankfurter Zeitung, o famoso diário liberal de Frankfurt, no qual os melhores nomes da intelligentsia da Alemanha de Weimar apareceram. Em 1931, como Max Horkheimer reconta em seu Prefácio à obra Punição e estrutura social (Rusche e Kirchheimer 1939, ix), "Dr. Georg Rusche sugeriu que ele fosse contratado para escrever um manuscrito que tratasse da inter-relação entre punição e mercado de trabalho". Nós não sabemos se o fato de Rusche "ter sido comissionado" significa que ele tinha algum tipo de relacionamento formal com o Instituto de Pesquisa Social de Frankfurt. No entanto, no arquivo de Rusche na Society for Protection of Science and Learning (SPSL I), encontramos uma observação sobre o fato de que ele "tinha bolsa de pesquisa do Instituto de Pesquisa Social da Universidade de Frankfurt" e se apresentou à Sociedade com cartas de Pollock e Horkheimer. Em 1933, um artigo de Rusche apareceu na segunda edição da revista do Instituto de Frankfurt, Zeitschrift für Sozialforschung. Todos os principais conceitos que mais tarde constituiram a estrutura do esboço final de pesquisa que estava terminando na mesma época, já estavam presentes nesse artigo. Sobre a relação entre o artigo de Rusche de 1933 e a obra Punição e estrutura social, ver Melossi (1978).

A análise "econômico-histórica" de Rusche (1933) da história da punição baseia-se na concepção "clássica" do funcionamento do mercado de trabalho, associada ao principio penal da dissuasão (Rusche 1933). Em contrapartida, ele não perde de vista as mudanças ocorridas no capitalismo moderno, especialmente o papel desempenhado pelas políticas de bem-estar social do Estado. Quando contrasta a situação alemã com a americana em seus artigos de 1930 e 1933, ele observa a relevância comparativa do bem-estar social, foco que mais tarde falta na reelaboração de Kirchheimer do rascunho original de Rusche. Como Rusche mesmo afirmou, a principal razão para a extrema decadência (e, portanto, para os tumultos) que estavam prejudicando o sistema penal americano era a ausência geral de provisões de assistência social que, por outro lado, mantinham os padrões de vida da classe trabalhadora alemã em um nível mais razoável, mesmo no meio da Depressão. Portanto, segundo Rusche, os padrões de vida nas prisões alemãs não precisavam cair para o mínimo intolerável

17 NT: Privatdozent designa o professor universitário que ainda não possui cátedra, mas que já tem livre docência (Habilitation)

18 NT: Dario Melossi, conforme se depreende das referências bibliográficas utilizadas, vale-se sempre, quando cita o trabalho Punição e estrutura social, da primeira edição, publicada e editada em 1939 pela Columbia University Press.

19 NT: O autor refere-se, aqui, à Grande Depressão de 1929. 
que atingiram nos Estados Unidos - em ambos os casos de acordo com a "máxima heuristica" (1933) do principio da menor elegibilidade -, que Rusche enfatizou após os escritores do laissez-faire dos séculos 18 e 19. Não vou entrar aqui em uma discussão sobre a relação da teoria de Rusche com o conceito de disciplina do trabalho, pois essa foi uma das questões críticas tratadas no meu artigo de 1978 (ver também Foucault 1977: Melossi e Pavarini 1980).

Por volta de 1933, quando ele estava concluindo o manuscrito de Arbeitsmarkt und Strafvollzug, ${ }^{20}$ os nazistas tomaram o poder, o que obrigou Rusche a emigrar, como era comum para a maioria das pessoas e instituições, a exemplo do Instituto de Frankfurt, que de alguma forma estavam comprometidos com a politica progressista na Alemanha (Jay 1973). Rusche foi para Paris e depois, presumivelmente, logo depois, para Londres. Não sabemos se Rusche teve alguma coisa a ver com as filiais do Instituto de Frankfurt nessas duas cidades (Jay 1973, 37, 38, 113). Em Londres, Rusche apresentou-se, assim como muitos outros estudiosos refugiados alemães, à Society for Protection of Science and Learning, fundada em 1933, com o objetivo de auxiliar estudiosos de outros paises que, por motivos religiosos, políticos ou raciais, eram incapazes de trabalhar em seu próprio país. Rusche, que tinha 33 anos na época, explicou os "motivos de sua demissão" da Alemanha em termos de ser "não ariano". Ele se apresentou como um homem solteiro "disposto a ir a qualquer lugar", cujos campos de estudo eram "sociologia, criminologia, economia" e cujas segundas linguas eram inglês e francês, além de "alguma coisa de" espanhol, italiano e holandês (SPSL I). Ele também apresentou inúmeras referências de estudiosos ilustres: do v. Beckerath e Pribram, mas também de Max Horkheimer, diretor do Instituto de Frankfurt e F. Pollock. Além disso, ele obteve referências em inglês, especialmente, do meio da progressiva London School of Economics (LSE) que, por um curto período, pareceu representar um possivel novo local para o Instituto de Frankfurt: Altschul, Robbins e Tawney. Lionel Robbins, o professor conservador de economia política e poderoso oponente da liderança de William Beveridge na LSE e o principal responsável pelo fracasso da LSE em comprar a Biblioteca do Instituto de Frankfurt, não estava muito entusiasmado com Rusche (SPSL I). Pode-se notar que a proposta de compra da biblioteca do instituto se tornou uma questão controversa nas lutas politicas e pessoais que estavam ocorrendo na LSE entre o conservador Robbins e Harold Laski, professor de ciência política e uma personalidade eminente LSE na ala esquerda do Partido Trabalhista (e entre Robbins e Laski contra Lord Beveridge). A compra da biblioteca foi vista como uma perigosa "infiltração marxista" na academia britânica e foi finalmente rejeitada (Harris 1977, 297-99). Considerando que a LSE era a instituição acadêmica britânica mais progressista, é fácil entender as dificuldades que os imigrantes de esquerda alemães tiveram que enfrentar na Grã-Bretanha, como veremos a seguir em maiores detalhes. No entanto, Robbins indicou Rusche para R. Tawney, um dos eminentes historiadores britânicos da época e professor de história econômica da LSE. A referência que Tawney fez de Rusche para a Sociedade foi altamente positiva, e ele recomendou calorosamente ajuda e incentivo (SPSL I).

Não obstante, Rusche não conseguiu encontrar uma ocupação estável e, em vez disso, trabalhou no Museu Britânico, dedicando-se a reescrever seu manuscrito em inglês "com a ajuda de um amigo inglês".21 De acordo com Urbach e Striesow, o "amigo inglês" poderia ter sido Rudy Davidson, que era muito próximo de Rusche naqueles anos. ${ }^{22}$ Como Martin Jay observou, "as oportunidades limitadas na Inglaterra para os estudiosos refugiados que começaram a sair da Alemanha em 1933 foram notadas com frequência" (1973, 38; Neumann et al. 1953). Rusche passou três anos em Londres, depois, em 1936, foi para a Palestina

20 NT: Mercado de trabalho e sistema penitenciário.

${ }_{21}$ Essa informação vem de uma carta de J. Gumperz para T. Sellin datada de 18 de janeiro de 1935. As informações a seguir sobre as correspondências entre J. Gumperz e T. Sellin são do arquivo privado do Professor Sellin.

22 Da conversa do autor em Londres com Philip Urbach em 9 de janeiro de 1979 e com Hannah H. Striesow em 10 de janeiro de 1979 
com Rudy Davidson. Na Palestina, ele ensinou na Escola Britânica de Jerusalém até a primavera de 1939, quando retornou à Grã-Bretanha.

\section{Punição e estrutura social}

É particularmente interessante observar o que aconteceu durante esse período com o manuscrito de Rusche e em suas relações com o Instituto de Frankfurt. Como apontado anteriormente, após as considerações do instituto sobre várias opções possiveis de realocação, como Paris, Londres e Genebra, a única possibilidade remanescente era os Estados Unidos, que já estavam recebendo um fluxo constante de imigrantes da Alemanha. Julian Gumperz, nascido nos Estados Unidos e, portanto, fluente em inglês e aluno de Pollock em Frankfurt desde 1929, foi enviado para os EUA em 1933, a fim de explorar a situação (Jay 1973, 38ss.). Ao longo dos anos, o instituto teve vários contatos com figuras proeminentes no mundo sociológico norte-americano: Charles Beard, Robert Maclver, Wesley Mitchell, Reinhold Niebuhr e Robert Lynd, todos na Columbia University (Jay 1973, 39). Gumperz relatou a Horkheimer que a situação parecia promissora. Em março de 1934, Gumperz voltou aos Estados Unidos e seguiu seus contatos com os principais sociólogos americanos. Em 19 de março, ele escreveu a Thorsten Sellin, que já era uma personalidade proeminente entre criminólogos e sociólogos americanos, explicando a intenção do instituto de ir aos Estados Unidos e sua situação precária em Genebra. Gumperz também conheceu Sellin e, aparentemente, mencionou o manuscrito de Rusche, porque em outra carta datada de 24 de março, ele escreveu que o livro sobre Strafvollzug ${ }^{23}$ seria enviado a Sellin. Como veremos, neste momento Rusche já estava trabalhando na tradução para o inglês, presumivelmente a pedido do instituto de Frankfurt. Esse detalhe é particularmente interessante porque mostra que, previamente (mesmo antes do presidente da Columbia, N. M. Butler, formalmente oferecer a Horkheimer a hospitalidade de sua universidade para a Escola, que ocorreu na primeira viagem de Horkheimer aos Estados Unidos, em maio de 1934), o instituto já estava levando em consideração a possibilidade de apresentar o manuscrito de Rusche como a primeira publicação do instituto nos EUA (e em inglês). Isso mostra tanto um certo grau de confiança no trabalho de Rusche (o que dificulta a compreensão dos acontecimentos subsequentes relativos à publicação do livro e às relações entre a escola e Rusche) quanto, também, um certo otimismo na possibilidade concreta da transferência do instituto para os Estados Unidos. Após alguns meses de silêncio, durante os quais, como vimos, foi alcançado um acordo entre Butler e Horkheimer, - e muitos dos principais membros do instituto (Marcuse, Lowenthal, Pollock) começaram a vir para os Estados Unidos - Gumperz escreveu novamente a Sellin em 6 de novembro, informando-o do "apoio amigável" de Maclver e Lynd em Columbia e da decisão de estabelecer o Institute for Social Research (como seria chamado) nas instalações da Columbia. Ele acrescentou que o pedido para obter uma tradução em inglês do manuscrito de Rusche "sobre administração penal [...] demorou mais do que o previsto" e formalmente pediu a Sellin que editasse o livro. Em 14 de novembro, Sellin confirmou o recebimento das 477 páginas datilografadas do manuscrito de Rusche em inglês.

Sellin leu o manuscrito e, em 18 de dezembro, escreveu de volta para Gumperz, oferecendo suas primeiras impressões do livro de Rusche:

\footnotetext{
Finalmente consegui concluir meu exame do manuscrito por Rusche. Não tive tempo de ler na integra. Eu me limitei mais ou menos à última metade do livro, especialmente as seções que se referem aos desenvolvimentos nos Estados Unidos [...] O manuscrito precisará de uma imensa quantidade de trabalho editorial antes de ser publicado [...].
}

Sellin continua apontando vários problemas relacionados à tradução, como a necessidade de adotar o estilo padrão de publicação americano, alguns problemas com as citações e, em seguida, várias correções das declarações de

${ }^{23}$ NT: Strafvollzug pode ser traduzido, ao português, tanto como punição quanto como execução da pena, ou mesmo como estabelecimento prisional, a depender do contexto. 
Rusche e dos dados sobre a história das prisões americanas. A crítica se torna mais dura à medida que a análise se concentra no periodo contemporâneo. Os dados de Rusche sobre superlotação são exagerados e incorretos. Isso vale também para alguns apontamentos que Rusche relata de outros autores sobre o tratamento brutal e a exploração de prisioneiros americanos durante a Depressão. Em conclusão, observa Sellin:

Só posso dizer que todo o tratamento do assunto, da página 413 a 422, estará aberto a críticas consideráveis. Há tanta coisa na tese do autor que são corretas, que chega a ser uma pena que ele assuma uma postura sensacionalista, em vez de adotar uma atitude acadêmica em relação às condições dos últimos anos. Nossos distúrbios na prisão começaram muito antes da depressão; nossa superlotação era pior antes da depressão do que depois; o pico da superlotação na Penitenciária Estadual do Leste da Pensilvânia, por exemplo, ocorreu por volta de 1925-26. Não há dúvida de que o desenvolvimento do crime organizado ou capitalista nos Estados Unidos após a guerra levou a uma revolta geral de juizes e magistrados contra o crime em geral. Isso resultou em sentenças mais longas e, igualmente importante, no uso muito mais cauteloso do probation e da paro$l e^{24}$, causando um tremendo crescimento da população carcerária em poucos anos, sem qualquer tentativa por parte dos legisladores de fornecer verbas para a ampliação das prisões; mas é interessante que no sistema federal, por exemplo, no qual o crescimento da população prisional foi fenomenal, o desenvolvimento das ideias humanitárias às quais o autor se refere em outros lugares atingiu seu auge nos nossos piores anos de depressão. Em outras palavras, embora eu admire muito o desenvolvimento geral da tese do autor e embora pense que há mais do que um grão de verdade nela, a aceitação sincera da teoria do determinismo econômico o levou a fechar os olhos para outros fatores que, embora possam não ser tão importantes quanto os fatores econômicos, tiveram um papel importante.

Em 11 de janeiro de 1935, Gumperz escreveu novamente a Sellin para informá-lo de que havia recebido a revisão de E.H. Sutherland do trabalho de Rusche e que o instituto gostaria que ele assumisse a tarefa de editar o livro em detalhes. Sellin aceitou e pediu o manuscrito original em alemão (carta 1/14/1935). Em 18 de janeiro, Gumperz respondeu:

[...] Lamento que o original em alemão não esteja disponivel aqui no momento, mas não acredito que seria de grande ajuda na edição do inglês, porque o autor fez algumas alterações substanciais ao traduzir o original em alemão para o inglês, com a ajuda de um amigo inglês em Londres. Além disso, estou anexando nesta carta uma cópia da carta do Dr. Sutherland.

Em janeiro de 1935, Rusche ainda estava em Londres. Não teria sido tão dificil, talvez um pouco problemático, pedir que ele enviasse o manuscrito original em alemão, deixando a Sellin, como editor do livro, o julgamento sobre a utilidade dessa versão anterior. Mas, como é evidente, Rusche parece ter sido completamente excluído de todo o processamento editorial do livro. Voltando à correspondência entre Gumperz e Sellin e à resposta de Sutherland a Gumperz (1/3/1935), é interessante notar que Sutherland, que também estava entre os mais eminentes criminólogos norte-americanos da época, prestou "atenção especial às partes da América" também. Depois de fazer algumas críticas, que, de fato, são muito semelhantes às apresentadas por Sellin, e que também se referem, em particular, à parte do manuscrito que trata da criminalidade organizada e do tratamento brutal, superlotação e tumultos em prisões americanas entre a Primeira Guerra Mundial e a Depressão, Sutherland tira uma conclusão mais geral:

Primeiro, considero que o mercado de trabalho é um fator altamente significativo na determinação de políticas penais, mas acho que a hipótese, conforme afirmada, é muito simples e que outros fatores também podem ser altamente importantes. Uma das melhores ilustrações do meu argumento é apresentada no aumento da severidade nas cortes e prisões americanas durante e após a Guerra Mundial. Foi um período de grande prosperidade, relativamente pouco desemprego e salários relativamente altos. Mas a severidade das penas aumentou,

24 NT: O termo "parole" pode ser traduzido literalmente por liberdade condicional. Nesse caso, optamos, também, por deixar o termo no original, considerando que nos Estados Unidos a liberdade condicional é concedida após um infrator ter cumprido uma parte de sua sentença de prisão. Assim, a liberdade condicional difere da "probation" por não ser uma sentença alternativa, mas sim um direito concedido a alguns reclusos depois que uma porcentagem de sua sentença tenha sido cumprida. As pessoas em liberdade condicional devem respeitar certos termos e condições enquanto estiverem nessa situação. 
a oposição ao trabalho nas prisões aumentou em comparação com vinte anos antes, o uso da probation diminuiu e outras mudanças de natureza semelhante ocorreram. Penso que a explicação é que uma alta taxa de criminalidade assustou os tribunais e o público e a severidade das penas foi uma reação a esse medo. Isso me faz pensar se durante todo o periodo coberto pelo manuscrito não é possível que muitas dessas influências tenham operado. Fiz um estudo sobre a população prisional decrescente da Inglaterra, durante os últimos oitenta anos, e minha impressão foi de que a taxa de criminalidade diminuiu e, como consequência, a severidade das penalidades também. Agora, certamente existe alguma relação entre ciclos de negócios e taxas de criminalidade, mas, como mostrou o estudo de Dorothy Thomas, a relação não é muito próxima. Em geral, minha reação é que a hipótese do manuscrito é muito simples para explicar todos os fatos. Segundo, tenho a sensação de que um argumento do tipo apresentado neste manuscrito não pode ser provado definitivamente. É possivel mostrar uma associação aproximada entre condições de trabalho e políticas penais, mas é sempre necessário, ao expor o argumento, que se selecione o material [...] esse processo seletivo pode ser mais ou menos completo. Seria possivel encontrar materiais em quase qualquer periodo que ilustram uma tendência oposta à hipótese [...]. Acho que isso fará um livro muito útil. Até onde eu sei, não há nada na literatura [de língua] inglesa que cubra o periodo e os materiais, ou que apresente a tese deste manuscrito. Espero que seja publicado prontamente.

É importante observar que Sellin e Sutherland apreciaram muito o trabalho de Rusche e o recomendaram calorosamente para publicação (apesar das reservas quanto à validade geral da hipótese de Rusche), mas também que ambos criticaram duramente as poucas páginas dedicadas à discussão da situação penal americana contemporânea. Entre o final de janeiro e o início de abril, Sellin examinou todo o manuscrito em detalhes e enviou suas anotações cuidadosas, página por página, de volta a Gumperz (cartas, 3/12/1935, 21/3/1935, 26/3/1935). A partir das notas de Sellin, é possivel deduzir que cerca de 60 páginas na versão original em inglês do texto de Rusche (que, assim como a alemã, foram perdidas), i. e, a parte final dele, tratou um pouco mais sobre a situação contemporânea nas prisões americanas (413-426) e a situação na Alemanha nazista (427-475). No final de março de 1935, o livro estava pronto para publicação, mesmo que, como Sellin observou ao concluir seu trabalho, o manuscrito ainda precisasse de mais "três semanas de trabalho editorial final".

O livro não seria publicado até 1939. Mais uma vez, do prefácio de Horkheimer ao livro Punição e estrutura social:

[...] Seguindo o conselho de eminentes autoridades americanas, o Instituto decidiu que era necessário um tratamento mais abrangente do assunto. Como o Dr. Rusche não estava disponivel para a reformulação de seu manuscrito, a tarefa foi atribuida ao Dr. Kirchheimer [...].

Por que Rusche "não estava disponivel"? Em 1935, ele ainda estava em Londres e, presumivelmente, também não teria sido tão difícil encontrá- lo na Palestina entre 1936 e 1939. Ele se recusou a refazer seu manuscrito? Ou o Instituto de Nova York simplesmente decidiu, por um motivo ou outro, atribuir essa tarefa a outra pessoa? Nenhum dos antigos membros ou associados do instituto que foram contatados tinha alguma ideia sobre qual seria o motivo. ${ }^{25}$ Eles mal conseguiam se lembrar do nome de Rusche e, de qualquer forma, depois que o instituto recebeu o primeiro manuscrito de Rusche, perderam toda a noção de seu paradeiro. Somente M. I. Finley, o conhecido aluno de história antiga, que, sob o nome de M. I. Finkelstein, estava ensinando na faculdade da cidade de Nova York e que ajudou Kirchheimer na tradução de seu novo manuscrito para o inglês, oferece uma observação sobre a afirmação de Horkheimer sobre a "não disponibilidade" de Rusche:

A frase de Horkheimer [...] foi um eufemismo.
As relações com Rusche eram bastante tensas,
para dizer o minimo, e acredito que o Instituto
teria preferido retirar seu nome completamente
do livro, mas não ousaram fazê-lo. Rusche
naquela época estava em Israel. ${ }^{26}$

Na falta de pistas que pudessem fornecer

\footnotetext{
25 Sobre isso, ver a carta de Herbert Marcuse para o autor, datada de 16 de maio de 1977; um discurso de Leo Lowenthal; a carta de Anne R. Kirchheimer para o autor, datada de 15 de fevereiro de 1978; e a carta de Alice Maier para o autor em 26 de novembro de 1979.

${ }^{26}$ A carta de M. I. Finley para o autor em 30 de janeiro de 1978
} 
uma explicação para essas "relações tensas", o assunto está aberto às mais diversas conjecturas: as próprias alterações do manuscrito de Rusche são a explicação? Ou a tensão no relacionamento tem a ver com um desacordo mais geral, baseado em razões politicas, culturais ou pessoais?

No entanto, como lemos em Horkheimer, a tarefa de "retrabalhar" o manuscrito foi atribuida a Otto Kirchheimer. Kirchheimer, estudante de direito e ciência política, e discipulo de Carl Schmitt, emigrou para Paris em 1934, onde pôde ingressar no ramo francês do instituto como pesquisador associado. Na França, ele escreveu para revistas sobre questões de direito penal (sobre a vida e as obras de Kirchheimer, particularmente as que me refiro aqui, veja meu artigo de 1978 e a bibliografia citada). Dada a sua educação, ele era o homem certo, portanto, a quem foi atribuido o "retrabalho" do manuscrito de Rusche quando ele chegou ao Instituto de Nova York, em 1937. O manuscrito de Rusche, então, foi arquivado por mais de um ano, entre 1935 e 1937. Não se sabe se o instituto decidiu desistir da publicação do trabalho de Rusche e mudou de posição com a oportunidade oferecida pela presença de Kirchheimer em Nova York ou se foi decidido desde o início que ele fosse retrabalhado por Kirchheimer. De qualquer forma, Kirchheimer trabalhou no manuscrito em Nova York, sem nenhum contato com Rusche (Marcuse, Sra. Kirchheimer, Sra. Maier, Finley e Sellin concordam com esse ponto.) Pelo que Finley escreve, concluimos que Kirchheimer reescreveu a coisa toda (ou, como veremos abaixo, parte dela) em alemão e, posteriormente, traduziu esse novo trabalho para o inglês com a ajuda de Finley. De fato, esse último escreve na carta citada:

Não me lembro de ter nada a ver com o manuscrito original de Rusche. Trabalhei diretamente e em estreita colaboração com Kirchheimer e tenho certeza de que a maior parte do trabalho era inteiramente dele.

Depois disso, o novo manuscrito foi novamente enviado a Sellin, que escreveu um Prefácio (no Prefácio, Horkheimer escreve que o professor Sellin "também examinou o trabalho revisado", mas
Sellin não se lembra disso). Horkheimer escreveu o Prefácio (datado de junho de 1938) e, em 1939. Punição e estrutura social foi publicado pela Columbia University Press como a primeira publicação em inglês do Instituto Internacional de Pesquisa Social, sob a autoria de Georg Rusche e Otto Kirchheimer.

Considerando o resultado, pode-se perguntar. com razão, que tipo de "retrabalho" foi conduzido por Kirchheimer no manuscrito original de Rusche. Em seu prefácio, Horkheimer afirma que Kirchheimer reteve "em essência os conceitos subjacentes ao rascunho original do Dr. Rusche nos Capítulos II a VIII; os capítulos restantes representam as próprias idéias do Dr. Kirchheimer". Como não temos o manuscrito alemão original de Rusche ou sua própria tradução para o inglês, a comparação entre o rascunho original e o resultado publicado não é fácil. As únicas fontes em que podemos confiar são os artigos de Rusche de 1930 e 1933 e as notas de Sellin comentando o rascunho em inglês de Rusche. Os capitulos II a VIII de Punição e estrutura social são claramente nada além de um desenvolvimento histórico da principal tese de Rusche, como é exposto em seus artigos de 1930 e, especialmente, em seus artigos de 1933 (Melossi 1978, 77). Tendo em vista que já havia um texto em inglês, revisado e editado por Sellin, pode-se perguntar se Kirchheimer sequer chegou a tocar em alguma coisa nesta parte do livro. Dos dois artigos de Rusche e das notas de Sellin, podemos inferir que os capitulos II a VIII de Punição e estrutura social não esgotam todo o desenvolvimento histórico originalmente coberto por Rusche. É possivel reconstruir que, no seu manuscrito, Rusche veio a testar sua tese sobre a relação entre o mercado de trabalho e as práticas penais durante o periodo que se seguiu da segunda metade do século passado à grande Depressão internacional da década de 1930. Nesta análise, ele prestou especial atenção à experiência americana e aos periodos de Weimar e dos primeiros anos nazistas na Alemanha. Kirchheimer lida parcialmente com esses temas nos capítulos IX e XI, mas de uma maneira muito diferente da de Rusche. A relação entre os padrões de vida da classe trabalhadora e as práticas 
penais é pouco abordada no capítulo IX, que trata do período 1880-1930. Esse capítulo ignora, por exemplo, a ênfase que Rusche, de maneira bastante consistente de acordo com sua própria tese, coloca no papel das provisões de bem-estar na alteração da "pureza" do relacionamento. Todas as dicas sobre as condições penais americanas são suprimidas. E, no capítulo XI, Kirchheimer lida com a política criminal nazista ao longo de outras obras que ele havia escrito ou estava escrevendo sobre o assunto, concentrando seu interesse em modificações na estrutura legal e constitucional. Essa mudança de atenção refletia, obviamente, seus próprios interesses e preocupações intelectuais, bem como os do instituto, mas evitava completamente o tipo de considerações socioeconômicas centrais às teses de Rusche e ao corpo principal do volume. Por fim, Kirchheimer acrescentou dois "novos" capítulos, sobre a "multa na prática penal recente" e a relação entre "politica penal e taxa de criminalidade".

Considerando o que é dito e o que não é dito (em comparação com o esquema de Rusche), a tendência na argumentação de Kirchheimer nesses quatro últimos capítulos (e no capítulo XIII, duas páginas de conclusão) parece inclinar-se para uma ênfase deslocada de considerações socioeconômicas para [considerações] politicas. Na reconstrução de Kirchheimer sobre as tendências contemporâneas, uma dizia respeito à diminuição da severidade nas práticas penais (exemplificada pela tendência descendente dos compromissos em relação à política penitenciária e pelo aumento das penas pecuniárias) nos paises europeus mais desenvolvidos é brutalmente interrompida e revertida pelo aumento dos regimes fascistas, isto é, a explicação é em termos políticos. Para argumentar, é necessário eliminar qualquer referência ao que estava acontecendo nos Estados Unidos, onde, como Rusche havia apontado em seus artigos de 1930 e 1933. a deterioração das condições penais era muito mais severa do que na Alemanha (pelo menos no período Weimar), e estava diretamente ligada à Depressão. A rigidez "econômica" da tese de Rusche é assim transformada em política.
Os motivos que justificam essa mudança se tornam mais evidentes quando a publicação de Punição e estrutura social está situada no contexto apropriado. O trabalho deveria ser o primeiro livro "americano" a ser publicado pelo instituto e apareceu em um momento caracterizado por insegurança política e em um clima pré-guerra que não favorecia a sobrevivência de um instituto que ostentava o título de "marxista", mesmo que de uma variedade não ortodoxa. Como foi observado, a liderança do instituto estava ciente desses perigos (Jay 1973, 44, 105. 204). Essa disciplina autoimposta certamente deve ter funcionado com relação ao "primeiro livro" da "nova série americana", a introdução do próprio Instituto ao público americano. É claro que outras considerações podem ser acrescentadas como, por exemplo, o fato de que a forte preferência de Rusche em favor de uma explicação econômica provavelmente não era do gosto do Instituto; ou que a preocupação com uma análise eminentemente antifascista não era apenas uma preocupação primária que afetava todas as políticas do instituto, mas também foi fortemente perseguida por Otto Kirchheimer e por outros membros que compartilharam sua educação político-jurídica (Melossi 1978, 78ss.). Diante de tudo isso, ainda assim, a decisão de publicar o livro com as alterações de Kirchheimer produziu um trabalho dividido em duas partes. A tese principal, exposta na primeira parte, não é desenvolvida na segunda. Mais crucialmente, o silêncio sobre os desenvolvimentos americanos mais recentes contradiz a própria essência da análise do instituto, que considerava o surgimento dos regimes nazistas e fascistas como uma personificação radical do estágio totalitário do desenvolvimento capitalista. Em suma, embora o livro ofereça uma explicação teórica das práticas penais nos estágios anteriores da história da explicação capitalista, que podemos ou não considerar adequadas, ele eventualmente falha em fornecer uma explicação para o capitalismo contemporâneo (Melossi 1978, 79ss.), uma falha que deve ser atribuida em parte ao próprio processo de sua "reformulação". 


\section{No exílio}

Em 11 de março de 1939, Rusche, que mantinha um visto de volta à Palestina válido até 25 de fevereiro de 1940, retornou a Londres. Ele nunca usaria o visto de retorno e não sabemos se ele pretendia fazê-lo (SPSL II). No entanto, através da Society for Protection of Science and Learning, ${ }^{27}$ Rusche pediu permissão ao British Home Office para permanecer na Grã-Bretanha. Rusche declarou à Sociedade sua intenção de fazer pesquisas e escrever sobre o tema "A economia do rearmamento". Ele deu como referência os nomes do professor Barn e do professor Dobb, o ilustre historiador marxista (SPSL II). Dobb citaria o livro de Rusche e Kirchheimer em sua principal obra $(1946,23,235,238)$. A partir da ligação que ele manteve com o Instituto em Nova York (e, especificamente, com seu diretor, Max Horkheimer), nesse período - uma correspondência que aparentemente continuou apesar das "relações extremamente tensas", provavelmente devido à situação bastante desesperadora de Rusche - soubemos que, como muitos outros estudiosos alemães refugiados, Rusche precisava de tudo. Ele procurava freneticamente um lugar para morar (todas as cartas têm um endereço diferente) e estava em busca de permissão do Ministério do Interior para permanecer, algo que deveria estar ligado a um emprego ou ocupação.

Rusche escreveu para Horkheimer em 5 de abril. ${ }^{28}$ Ele se candidatou a uma Leon Fellowship na Universidade de Londres e pediu a Horkheimer que escrevesse uma carta de recomendação. Ao se candidatar à bolsa, ele apresentou um programa de pesquisa que tratava de: Aeconomia do rearmamento alemão. Ele explica suas intenções a Horkheimer:

Quero dizer com isto: um estudo - cuja ideia, há algum tempo, tem sido cada vez mais importante para mim - de uma natureza principalmente teórica. O estudo deveria abordar os problemas, primeiro, de como um desvio tão incrivel dos ensinamentos da economia tradicional pode funcionar - e aqui os desenvolvimentos mais recentes da teoria do monopólio, da teoria da concorrência limitada e do intervencionismo devem ajudar - e como de fato ele se arrasta para essa armadilha peculiar, tanto do ponto de vista financeiro, quanto do mais econômico. Acredito estar bem qualificado para esta pesquisa e, nesse campo, ser capaz de me sair muito melhor do que os estudantes habituais deste tema, que enfrentam o problema sem uma formação teórica razoável e, especialmente, sem a força necessária de pensamento. Não é apenas a minha boa qualificação que me impõe a escolha deste tema, mas também é, e muito mais, a questão de fato de sua atualidade sinistra. Visto que, de fato, a Inglaterra pode ser levada a seguir o exemplo alemão, minha pesquisa pode descobrir resultados de interesse vitale de grande utilidade, não apenas em meros termos acadêmicos, mas também politicamente, devido ao seu valor prático em tornar possível aprender com o exemplo alemão, para imitar o que deu certo e evitar os erros.

Rusche continua nesta carta se referindo à sua situação extremamente precária na Inglaterra. A ajuda da Society for Protection of Science and Learning é apenas temporária. Ele poderia ser deportado a qualquer momento para os Estados Unidos ou para a Índia; isso provavelmente dependia da sua capacidade em conseguir um emprego ou uma ocupação. Ele pede outras referências a Horkheimer e cópias do livro, Punição e estrutura social, por meio das quais, acrescenta, ele conseguirá impressionar não apenas seus defensores acadêmicos, mas, mais importante, também seus defensores "políticos e sociais". A última parte da carta trata de um possivel artigo de Rusche para a revista do instituto:

No que diz respeito à entrega de um artigo
meu para a sua revista, estou feliz e pronto para
trabalhar no tema que você sugeriu, nos de-
senvolvimentos mais recentes da politica penal
alemã. E há novos fenômenos verdadeiramente
interessantes na Alemanha, como consequência
da inacreditável escassez de trabalhadores.

Rusche está se referindo aos campos de concentração? Em termos de sua teoria, faria sentido interpretar a politica de trabalho forçado nazista (em 1939!) como uma resposta à terrivel fome de poder em relação à força de trabalho da indústria

\footnotetext{
27 Society for the Protection of Science and Learning. I Rusche's file. London: Archive of the Society.

28 Toda a correspondência citada neste artigo, entre Rusche e o New York Institute, está no Pollock-Archiv, Frankfurt. Quando não indicado de outra forma, as cartas são em alemão e a tradução para o inglês é minha.
} 
alemã (uma política que continuaria durante a guerra como um reflexo do todo da ideologia nazista de uma "Nova Ordem", na qual as raças "inferiores" trabalham vigorosamente sob o dominio das "superiores"). A observação de Rusche pode fornecer uma dica do que sua seção na Alemanha contemporânea teria tratado, provavelmente apontando a relação entre a escassez de trabalho livre e a criação político-militar de um pool de trabalho forçado (nesta relação, ver também Sellin 1976, que escreveu sob a influência do trabalho de Rusche e Kirchheimer, mas que não lidou com o caso nazista na Alemanha). Mas, em sua carta, Rusche não desenvolve o assunto. Pelo contrário, ele reclama das dificuldades em reunir o material necessário e acrescenta:

Como seria, então, se, enquanto isso, eu entregasse um artigo no qual meus pensamentos sobre a teoria social e econômica de uma ditadura seriam discutidos em conexão com meu trabalho planejado sobre a economia de guerra alemã? Acho que tenho algo a dizer sobre os pré-requisitos técnicos da democracia e do fascismo, suas origens nas respectivas constituições tecnológicas, sua união com as formas modernas de produção e financiamento de monopólio [...].

Devido ao intenso envolvimento que teve com esse tema, ele conclui que poderia escrever sobre esse assunto em um tempo muito menor.

Em uma carta subsequente, datada de 14 de junho do mesmo ano, Rusche ainda está pedindo a Horkheimer que lhe envie documentos (de sua associação com o instituto?), cópias de Punição e estrutura social e cartas de recomendação. Ele não recebeu a Leon Fellowship e, portanto, perdeu a chance de fazer pesquisas sobre a economia de guerra alemã. Ele aponta a possibilidade de escrever o artigo sobre desenvolvimentos penais, mas, mais uma vez, também as dificuldades em reunir os materiais. Também comenta o trabalho de Kirchheimer em Punição e estrutura social e afirma:

Lamento ser obrigado a dizer que, no trabalho do Dr. Kirchheimer, existem várias fraquezas que não pertencem ao livro e que eu lamento muito.

Rusche não se aprofunda no assunto. Isso é bastante compreensivel em uma carta em que ele foi obrigado, por sua situação em Londres, a pedir a Horkheimer (que, assim como o diretor do instituto, era o principal responsável por suas escolhas editoriais) por uma série de favores, mesmo que, por outro lado, os sentimentos de Rusche sobre a "reformulação" de Kirchheimer de seu manuscrito original provavelmente fossem fortes demais para permitir que ele omitisse completamente qualquer referência a eles. No final, ele pergunta a Horkheimer se há alguma chance de encontrar trabalho nos Estados Unidos. Algum tipo de resposta ao pedido de Rusche veio de Horkheimer em 28 de junho de 1939, com uma carta em inglês endereçada "a quem possa interessar":

O Dr. Georg Rusche está conectado com este Instituto há quase dez anos. Ele veio até nós altamente recomendado por vários estudiosos que o acompanharam durante sua formação, especialmente como uma pessoa talentosa e trabalhadora. Em 1931, o Dr. Rusche nos enviou o plano de um extenso estudo sociológico sobre a história da punição nos tempos modernos. Naquele momento, pedi que expressasse suas ideias em um primeiro rascunho. O resultado foi um artigo que publicamos em nosso Zeitschrift für Sozialforschung, vol. II (1933), pp. 63-78, intitulado "Arbeitsmarkt und Strafvollzug" (Mercado de Trabalho e Punição). Este artigo me convenceu de que o Dr. Rusche era a personalidade certa para fazer um estudo abrangente sobre o assunto especial escolhido por ele. Ele trabalhou por alguns anos fazendo estudos de fontes em escala internacional. O resultado é o livro "Punição e Estrutura Social", de Georg Rusche e Otto Kirchheimer, Columbia University Press, Nova York, 1939, PP. 257. Na opinião unânime dos especialistas, o trabalho constitui uma contribuição importante e inteiramente nova para a história social das instituições legais. Nesse sentido, o célebre criminólogo americano Professor Thorsten Sellin escreveu um prefácio ao livro. Infelizmente, os meios do Instituto não permitem oferecer ao Dr. Rusche um cargo como pesquisador associado. Em vista das excelentes qualificações científicas do Dr. Rusche, que me foram demonstradas não apenas pelo artigo e pelo livro, mas por inúmeras discussões científicas que tivemos, seria uma grande satisfação se ele tivesse em breve uma oportunidade adequada para o ensino ou a pesquisa.

Certamente, os "meios do instituto" que, entre 1934 e 1944, foram suficientes para apoiar "cerca de duzentos imigrantes" (Jay 1973, 114, 115, 168), 
também foram restringidos por um julgamento sobre Rusche e não é de surpreender que, após as "relações tensas" dos anos anteriores, o instituto não estivesse ansioso em ter Rusche em Nova York como pesquisador associado, mesmo que, como já foi observado, a natureza exata desses "problemas" tenha permanecido um tanto obscura. Rusche escreveu novamente em 6 de agosto para agradecer a Horkheimer por sua carta de recomendação e pedir outras cópias de seu livro e de Kirchheimer, porque teve que entregá-las a alguns professores, altos funcionários públicos do governo e outros. Ele escreveu que não tinha sido capaz de trazer dinheiro consigo e, portanto, não podia pagar pelos livros, que deveriam ser enviados a ele gratuitamente. Reiterou que, para ele, era uma questão de importância "absolutamente vital", provavelmente uma referência aos seus esforços em encontrar algum tipo de ocupação.

A próxima carta disponivel de Rusche a Horkheimer é datada de 15 de março de 1941. Foi escrita "após um periodo muito longo de internação", da qual Rusche foi libertado "cerca de seis semanas atrás" (ou seja, entre janeiro e fevereiro de 1941). Por que Rusche foi internado e quando? Não é possivel lidar aqui com o complexo problema histórico representado pela internação de refugiados na Grã-Bretanha em 1939 e 1940 (ver esp. Lafitte 1940 e Jaeger 1955; mas também: Proudfoot 1957; Link ed. 1968; Sherman 1973; Stevens 1975; Gillman e Gillman 1980). Apenas alguns fatos básicos serão oferecidos aqui, a fim de permitir uma compreensão do que aconteceu com Rusche.

Em setembro de 1939, um mês depois de Rusche ter escrito a última carta a Horkheimer examinada acima, foram criados tribunais na Inglaterra para classificar "estrangeiros inimigos" (alemães e austríacos) e para decidir se eram refugiados genuínos. Os casos seriamente suspeitos deveriam ser colocados na classe "A", os certamente não suspeitos na classe " $C$ " e os duvidosos na classe "B". A classe A (cerca de 600) deveria ser internada imediatamente; os B deveriam ser submetidos a algumas formas de liberdade restrita (eram cerca de 7.000); nenhuma ação foi tomada em relação aos 65.000 membros restantes da classe C. Mas em maio e junho de 1940, o pânico generalizado relacionado à invasão da França e à entrada da Itália na guerra provocou a decisão de reunir e internar todos os da classe $\mathrm{B}$, muitos da classe $\mathrm{C}$ e todos os italianos, de modo que, em julho de 1940, aproximadamente 30.000 pessoas foram internadas. Durante o mesmo periodo, também foi instituída uma política de deportação para a Austrália e o Canadá. A maneira pela qual a designação dos grupos A e B foi conduzida posteriormente deu origem a fortes polêmicas, porque a maioria dos que foram presos no verão de 1940 eram refugiados genuinos. Não apenas foram cometidos muitos erros, muitas vezes, devido a razões burocráticas (problemas com as autoridades de imigração etc.), mas também um grupo muito definido de esquerdistas (brigadistas antifascistas da Espanha, pacifistas, socialistas e comunistas) foi considerado tão perigoso quanto as pessoas com simpatias nazistas ou fascistas, tendo sido internado junto com estes últimos (Lafitte 1940, 123ss.).

Rusche acrescenta, em sua carta de 1941, que ele foi deportado no Arandora Star para o Canadá, um navio que foi torpedeado e afundado em 2 de julho de 1940. Esse episódio foi central para chamar atenção do público para as realidades do internamento e para políticas de deportação, especialmente a maneira altamente questionável pela qual essa política foi realizada. O episódio também foi responsável por desencadear dois importantes debates no Parlamento Britânico, após os quais o processo de revisão das políticas de internação foi lentamente iniciado (Lafitte 1940). F. Lafitte, em seu panfleto fortemente polêmico contra a internação, reproduz o relato anônimo de um sobrevivente do torpedo (1940, p. 138ss.), que lança luz sobre todo esse caso. No campo em que esse escritor anônimo foi internado, havia três categorias de pessoas trancadas: cerca de 240 prisioneiros de guerra nazistas (marinheiros), "cerca de 200 judeus que haviam sido internados por tribunais ou pela polícia, alguns estando lá desde o início da guerra, alguns [...] sem vistos, que já haviam brigado com organizações de refugiados, já haviam sido punidos antes, não agradaram o juiz dos Tribunais [...]" e "cento e quarenta anti-fascistas: combatentes da Brigada 
Internacional na Espanha; antifascistas tchecos; refugiados políticos progressistas; refugiados austríacos" e assim por diante (os nomes de muitas pessoas desses grupos estão anexados e entre eles se encontram os principais sociais-democratas alemães e austriacos). A maioria das pessoas nesse campo foi deportada. O Arandora Star tinha a bordo pessoas recolhidas de diversos campos, somando um número entre 1.700 e 1.900. Apenas cerca de 600 sobreviveram ao torpedeamento do navio, a maioria dos quais eram prisioneiros de guerra nazistas que, em virtude de ainda estarem organizados militarmente e serem ex-marinheiros, conseguiram tomar posse dos botes salva-vidas às custas de outros. Vários conhecidos antifascistas alemães, austríacos e italianos se afogaram. A maioria dos alemães e austríacos do Arandora Star pertencia à classe $A$; isso sugere algo sobre os critérios de classificação dos tribunais.

Em suas conclusões, Lafitte (1940, 181-91) insinua que, por meio da política de internação, o governo britânico conservador quis atacar tanto à direita quanto à esquerda, sem levar em consideração a posição antinazista de muitos dos refugiados internados. Isso era particularmente verdade no caso dos comunistas, cuja política também era determinada pelo papel da União Soviética na guerra. Na época, era comum entre os refugiados de esquerda na Inglaterra interpretar a prisão de todos os alunos "alienígenas" de Harold J. Laski como sendo em razão de sua conexão com a guerra entre a Finlândia e a Rússia (no inicio de 1940), do mesmo modo que sua soltura veio a ser interpretada como estando conectada à entrada da União Soviética na guerra contra a Alemanha (junho de 1941).29 Em todo o caso, a intensificação do movimento anti-internamento na Inglaterra e a ameaça enfraquecida de invasão provocaram, primeiro, a interrupção da política de deportação e, posteriormente, a libertação gradual dos internos durante os primeiros meses de 1941.

Rusche estava entre aqueles que conseguiram sobreviver ao naufrágio do Arandora Star e estava em Cambridge quando escreveu para Horkheimer, em março de 1941. Ele ainda enfrentava os proble- mas extremamente dificeis que havia abordado antes da sua internação - problemas que, agora, haviam se acentuado muito devido à situação de guerra e às dificuldades do período de internação. Na carta já citada várias vezes (Rusche 1941), e agora reproduzida na íntegra, Rusche escreve:

\section{Caro professor Horkheimer.}

De volta ao mundo, depois de um longo periodo de internação, estou lentamente retomando contatos. É por isso que hoje estou escrevendo para você sobre mim. Fui libertado há cerca de 6 semanas e acho bastante dificil me estabelecer novamente neste mundo em mudança. Gostaria de saber se você poderia me ajudar de uma maneira ou de outra. É possivel que eu consiga trabalho de guerra e, é claro, então estaria totalmente ocupado, mas é possivel que eu não consiga. Neste caso, tenho duas possibilidades em mente. A primeira é fazer algum tipo de pesquisa, a outra é um tanto peculiar, mas me assombra dia e noite. Quando eu estava internado, eu obviamente não tinha instalações para pesquisa e, assim, comecei a escrever minha vida e meus pensamentos. Começou com meus pais, a atmosfera de um casamento misto na Alemanha imperial, infância, o Corpo de Cadetes, a guerra, o periodo de inflação, estudos, em casa e no exterior. Paris, Londres, trabalho, experiências na prisão e serviço social, Saxônia, Universidade de Frankfurt, imigração, Paris, Londres, Palestina, Londres novamente, internação. Foi uma "crônica de vida brutal" ("schonungslose Lebenschronik") e as partes que li dela para colegas internos que eram altamente críticos encontraram sua aprovação total. Infelizmente, todo o manuscrito pereceu, quando eu seria enviado para o Canadá e o "Arandora Star", no qual estávamos viajando, foi torpedeado. Perdi todos os meus pertences, mas lamento mais ter perdido este manuscrito. Agora, eu gostaria muito de reescrevê-lo, porque acho que vale a pena e pode ser o melhor serviço que eu poderia prestar neste momento. Infelizmente, sou incapaz de fazer isso sem ajuda e me pergunto se você talvez esteja em posição de me ajudar. O trabalho pode ser de grande interesse para você, não apenas como matéria-prima para estudos históricos e sociológicos, mas também por causa de meus próprios pensamentos, que. embora não os desenvolva sistematicamente, fazem parte do meu desenvolvimento e, portanto, da história. Ficaria muito grato se você pudesse ver um caminho para me ajudar. Ainda the devo um artigo, cuja entrega foi adiada pela guerra, mas isso realmente valeria mais do que tudo até agora.

29 Da conversa do autor com Hannah H. Striesow, Londres, 10 de janeiro de 1979. 
Com os melhores cumprimentos,

George [sic!] Rusche

Em 10 de abril de 1941, o instituto responde a Rusche:

Isso é para confirmar o recebimento da sua carta de 15 de março ao Dr. Horkheimer, que, infelizmente, não conseguiu responder antes de partir para uma longa viagem pelos Estados Unidos. O Dr. Horkheimer planeja visitar várias universidades para discussões com colegas. Fico feliz em saber com a sua carta que você é capaz de prosseguir com seu trabalho cientíico e literário e acho uma boa ideia que você pretenda escrever a história de suas experiências pessoais e científicas. Posso bem imaginar que seus grandes dons literários tornarão o próximo livro de importância documental para o desenvolvimento de uma geração inteira. Ficaremos contentes se você nos permitir ver o manuscrito quando ele terminar ou quando a maior parte tiver sido finalizada. Temos uma ou outra conexão com editores americanos e, é claro, ficaria feliz em fazer o que estiver ao nosso alcance para ajudá-lo na publicação. Se você conseguir escrever um artigo para nosso periódico em um futuro não muito distante, isso será útil. Suas chances de uma carreira acadêmica nos paises anglo-saxões certamente aumentariam se você pudesse apresentar essas publicações. É claro que sou incapaz de lhe dar uma promessa definitiva em relação a esse artigo antes de o vermos, mas aqui, novamente, você tem o conhecimento de que, se não conseguirmos publicar o artigo, poderiamos pelo menos entrar em contato com outras publicações científicas. Lamento dizer que, atualmente, não estou em condições de oferecer nenhuma esperança de ajuda financeira. Devido à ajuda que nosso Instituto estendeu a muitos estudiosos que fugiram da barbárie na Europa, nossos próprios fundos foram consideravelmente reduzidos. Atualmente, o maior número de assistentes vive de subsidios obtidos de fundações americanas. É, no entanto, impossivel obter uma bolsa para um estudioso que não mora neste país. Se nossa situação mudar para melhor, teremos o maior prazer de fazer o possivel para ajudá-lo. Com todos os bons votos a você pessoalmente e pela continuação do seu trabalho, sinceramente, o seu. (A cópia da carta, em inglês, no "Pollock-Archiv", não está assinada; o autor pode ter sido Pollock, que era o gerente administrativo do Instituto na época.)
Essas duas cartas são as evidências finais que iluminam a relação entre Rusche e o instituto.

Durante esse periodo, Rusche contratou Philip Urbach, que era muito jovem na época, como um amanuensis ${ }^{30}$ para escrever The quivering scales, ${ }^{31}$ um estudo sobre politica internacional. Urbach permaneceu muito perto de Rusche até a morte de Rusche. Outros conhecidos de Rusche nesse periodo foram Paul Weiss e os Striesows. A partir da carta de Paul Weiss ${ }^{32}$ e de conversas com Philip Urbach e Hannah Striesow, ${ }^{33}$ é possivel obter uma melhor compreensão da personalidade e do estado de espírito de Rusche, especialmente a partir do momento em que foi libertado do internamento. Essas três pessoas são as únicas que me disseram que conheciam Rusche; todas as pessoas de alguma forma associadas ao Instituto de Frankfurt e depois de Nova York que foram contatadas mal reconheceram a existência de Rusche e de seu manuscrito, e não puderam me dizer nada sobre ele; outras pessoas, indicadas como conhecidas de Rusche na Grã-Bretanha, negaram ter ouvido o nome dele.

Paul Weiss, que o conheceu pela primeira vez na Inglaterra no início de 1934, alguns meses após a emigração de Rusche, mas que começou a vê-lo com mais frequência após a libertação de Rusche do internamento, escreve:

Minha impressão sobre ele, quase desde o início, foi a de um homem altamente inteligente e talentoso, basicamente muito bondoso e, acho, originalmente bastante idealista, que, no entanto, por razões principalmente enraizadas em sua personalidade e, talvez, em parte hereditárias (ele tinha uma irmã altamente neurótica na fronteira da sanidade de quem ele tentava cuidar e que the causava muitos problemas) ficou desiludido e renunciou no momento em que o conheci e, com o passar dos anos, tornou-se progressivamente mais amargo e cínico [...]. Sua infelicidade era provavelmente agravada pela incerteza da época, pela situação politica geral e pelas dificuldades que os refugiados tinham que enfrentar. Mas acho que tudo isso foi secundário aos conflitos internos. [...] Seu intelecto quase não foi prejudicado durante esses anos. Ele havia perdido todo o

NT: O termo, em latim, refere-se ao papel desempenhado por um copista.

NT: As balanças trêmulas.

Weiss, Paul.1979. Letter of Paul Weiss to the author of this essay, July.

Das conversas do autor em Londres com Philip Urbach, em 9 de janeiro de 1979, e com Hannah H. Striesow, em 10 de janeiro de 1979. 
trabalho e estudos, mas as conversas com ele eram geralmente interessantes e ele manteve uma capacidade de entusiasmo quando ouvia uma boa observação ou uma boa história. Ele não era um mau contador de histórias.

Urbach e Striesow concordam com esta avaliação. Quando Urbach conheceu Rusche em 1941, Rusche "não era mais um homem ativo".34 Segundo Weiss e Urbach, Rusche costumava ter uma "conversa fascinante" sobre seu assunto favorito, a instabilidade dos equilibrios de poder nas relações internacionais, sob o título The Quivering, mas Urbach nunca viu uma linha sequer disso. Por outro lado, ele não parecia interessado em trabalhar naquela "schonungslose Lebenschronik"35 sobre a qual escrevera para Horkheimer. Desde sua emigração forçada da Alemanha, e ainda mais desde seu internamento, Rusche parece ter se dedicado a uma reconsideração de sua vida e crenças que tendia a se inclinar progressivamente para um estado de desespero e pessimismo e, eventualmente, para o pensamento da morte.

De acordo com as lembranças de Urbach, que são amplamente compartilhadas por Striesow, o último período da vida de Rusche foi enormemente infeliz e perturbado. Uma pessoa de inteligência extraordinária e um maravilhoso contador de histórias, tornou-se cada vez mais isolado, alienado e autoindulgente. Sua homossexualidade, que estava longe de ser tolerada na Inglaterra durante esses anos, sem dúvida complicou ainda mais sua existência. Dada sua educação de classe alta na Alemanha de Weimar, era difícil para ele se adaptar às dificuldades da guerra, ao exilio e ao ostracismo intelectual. Ele estava inclinado a continuar gastando dinheiro e foi forçado a pedir emprestado a todos os seus amigos. De alguma forma, ele se envolveu com algum tipo de ilegalidade mesquinha que, em 1950, pouco antes de sua morte, o levou à prisão por fraude relacionada a "transações de propriedade" indevidas! ${ }^{36}$
Durante os anos da guerra, Rusche mudou de lugar para lugar, geralmente ensinando nas escolas para "desajustados" ou filhos de refugiados. Após um intervalo muito curto na Universidade de Exeter como assistente de pesquisa em economia, no final de 1941, Rusche começou a lecionar na famosa Escola Summerhill of Alexander $S$. Neill, onde permaneceu de 1941 a 1943. Urbach também esteve presente na escola durante esse período. Vale a pena notar que essa é a única ocasião em que Urbach viu Rusche pegar uma caneta na mão para escrever algo para o jornal da escola, The Summerhillian, editado pelo próprio jovem Urbach. Em 1944 e 1945, Rusche ensinou no Slyne Lodge, um internato para filhos de refugiados judeus, perto de Lancaster, onde comprou uma casa. Urbach afirma que esse ensino não era muito importante para Rusche. Era apenas uma maneira de ganhar a vida e, como Urbach coloca, Rusche sempre parecia "ausente" quando estava ensinando. Após uma curta estadia em outra escola, perto de Worcester, Rusche voltou para Londres. Quando a guerra terminou, sua mãe e sua irmã, Marianne, que acabara de se casar com um inglês, se mudaram da Alemanha para Londres, fato que, segundo as lembranças de Urbach e Weiss, não contribuiu para a estabilidade psicológica de Rusche.

No periodo pós-guerra, as coisas não foram muito melhores para Rusche. Ele estava dando aulas em Londres na Workers' Educational Association (WEA), provavelmente dando sua palestra favorita sobre política internacional. Aparentemente, Rusche era um palestrante tão bom que, ocasionalmente, os ouvintes das palestras da WEA o paravam na rua para parabenizá-lo. ${ }^{37}$ Rusche estava ligado a um grupo de imigrantes alemães, dos quais Weiss e Striesows faziam parte, o qual era caracterizado como "trabalhista de esquerda".38 Urbach e Striesow excluem qualquer possibilidade de contato da parte de Rusche com a política britânica nesse periodo,

\footnotetext{
34 Da conversa do autor com Philip Urbach, Londres, 9 de janeiro de 1979.

NT: poderia ser traduzido como "uma crônica de vida brutal".

Das conversas do autor em Londres com Philip Urbach, em 9 de janeiro de 1979, e com Hannah H. Striesow, em 10 de janeiro de 1979

Da conversa do autor com Philip Urbach, Londres, 9 de janeiro de 1979

Da conversa do autor com Hannah H. Striesow, Londres, 10 de janeiro de 1979
} 
mas Striesow o define como "um social-democrata desiludido", um sentimento que foi bastante difundido na geração de Rusche e de seus amigos, como resultado de suas próprias vicissitudes pessoais e da experiência política mais geral de sua geração. Eles testemunharam o fim da democracia de Weimar e a ascensão ao poder do fascismo, a transformação da revolução soviética no stalinismo e a vitória de um modelo social que lhes era quase tão estranho quanto o fascismo ou o stalinismo, isto é, a sociedade de massas americana. Mesmo para aqueles que, em suas práticas políticas ou científicas, se voltaram para o socialismo e o marxismo, o apego aos antigos valores "liberais" e "individualistas" do mundo em que haviam crescido ainda era muito forte. Isso parece ter sido particularmente verdadeiro no caso de Georg Rusche e, provavelmente, essa tendência foi aumentada por alguma mistura das experiências de sua geração e de suas próprias experiências desesperadoras, culminando em crescente amargura e cinismo.

Weiss descreve Rusche como sendo "na doutrina econômica [...] um liberal absoluto e descarado",30 mesmo que pronto para admitir que essa "teoria correta dificilmente é prática" no mundo contemporâneo. Em seu trabalho teórico, a perspectiva da economia tradicional está certamente presente desde o início, filtrada pelas personalidades influentes em sua educação (Nelson, Pribram e, indiretamente, Oppenheimer), uma influência que é particularmente aparente, na minha opinião, no papel central que Rusche atribuiu à categoria "mercado de trabalho". Por outro lado, a tendência geral de seu trabalho científico e o caráter de suas associações ao longo da vida (o liberalismo socialista de Nelson, a Escola de Frankfurt, a esquerda do meio acadêmico britânico e a imigração alemã na Inglaterra) definem-no claramente como um militante à esquerda do espectro político e cultural. Mas essa militância foi dominada pelo que provavelmente era um sentimento de derrota, um sentimento que não era apenas dele, mas também de sua geração. Vale ressaltar que entre os livros sobre política contemporânea e os relatos autobiográficos que constituiram as leituras de Rusche durante esse periodo, entre seus favoritos, havia um livro de Hans B. Gisevius intitulado To the bitter end (1947), sobre os desaparecimentos da Alemanha entre os períodos nazista e da guerra, e Just as I feared, que lida com a deterioração das esperanças após a revolução soviética. ${ }^{39}$

Se essas considerações forem adicionadas às dificuldades que Rusche teve que enfrentar desde que deixou a Alemanha e seus profundos e psicológicos "conflitos internos" aos quais Weiss se refere, não é de surpreender que nesses últimos anos ele tenha mantido longas discussões com seus amigos sobre se deveria ou não se suicidar. ${ }^{40} \mathrm{O}$ episódio de sua prisão em 1950, em conjunto com a acusação de fraude e a perspectiva de um julgamento e provável condenação, constituiram nada mais que o golpe final. Em 19 de outubro de 1950, depois de várias noites discutindo seu suicídio, Rusche voltou para casa e executou seu plano, envenenando-se com gás de carvão doméstico, na pequena casa de Uxbridge nos subúrbios de Londres, onde morava sozinho.

\section{Referências}

Dobb, Maurice. 1946. Studies in the development of capitalism. London: Routledge \& Sons.

Foucault, Michel. 1977. Discipline and punish. New York: Pantheon Books.

Gillman, Peter and Leni Gillman. 1980. Collar the Lot. London: Quartet.

Gisevius, Hans B. 1947. To the bitter end. Boston: Houghton Mifflin Co.

Harris, Jose. 1977. William Beveridge: a biography. Oxford: Clarendon Press.

Jaeger, H. 1955. Refugees' Internment in Britain 193940. The Wiener Library Bulletin I9, 5-6.

Jay, Martin. 1973. The dialectical imagination. Boston: Little, Brown \& Co. https://doi.org/10.3817/0673016146

Lafitte, F. 1940. The internment of aliens. Harmoridsworth: Penguin Books.

39 Da conversa do autor com Philip Urbach, Londres, 9 de janeiro de 1979.

40 Das conversas do autor em Londres com Philip Urbach, em 9 de janeiro de 1979, e com Hannah H. Striesow, em 10 de janeiro de 1979 
Link, Werner. 1964. Die Geschichte des Internationalen Jugend-Bundes (IJB) und des Internationalen Sozialistischen Kampf-Bundes (ISK). Meisenheim am Glan: Verlag Anton Hain.

Link, Werner, ed. 1968. Mit dem Gesicht nach Deutschland. Dusseldorf: Droste Verlag.

Marcuse, Herbert. 1955. Reason and revolution. New York: Humanities Press.

Melossi, Dario. 1978. Georg Rusche and Otto Kirchheimer: punishment and social structure. Crime and Social Justice 9 (Spring Summer). https://doi.org/10.1007/9781-349-27927-2

Melossi, Dario e Massimo Pavarini. 1980. The prison and the factory. London: MacMillan.

Neumann, Franz et al. 1953. The cultural migration. Philadelphia: University of Pennsylvania Press.

Pribram, Karl. 1949. Conflicting patterns of thought. Washington, D. C.: Public Affairs Press

Pribram, Karl. 1935. Cartel problems. Washington, D. C: The Brookings Institution.

Pribram, Karl. 1931. World-unemployment and its problems. In Unemployment as a world-problem, editado por Q. Wright e Karl Pribram, s. p. Berkeley: The University of California Press.

Pribram, Karl. 1912. Die Entstehung der individualistischen Sozialphilosophie. Leipzig: Hirschfeld.

Proudfoot, Malcolm J. 1957. European refugees: 1939-52. London: Faber and Faber Ltd.

Rusche, Georg. 1941. Rusche's letter to Horkheimer, in English, March 15. Pollock-Archiv, Frankfurt.

Rusche, Georg. 1933. Arbeitsmarkt und Strafvollzug. Zeitschrift für Sozialforschung, 11:63-78. English trans.: Labor market and penal sanction. Crime and Social Justice 10 (Fall-Winter). https://doi.org/10.5840/zfs193321115

Rusche, Georg. 1930. Zuchthausrevolten oder Sozialpolitik. Zu den Vorgängen in Amerika. Frankfurter Zeitung (June 1). English trans.: Prison revolts or social policy: lessons from America. Crime and Social Justice, 13 (Summer).

Rusche, Georg. 1929. Bemerkungen zur logischen Grundlage der theoretischen Ökonomik. Leipzig: Thalacker \& Schöffer.

Rusche, Georg. 1924. Bemerkungen zum Rechtsbegriff und zu den Grundsätzen der philosophischen Rechtslehre. Dissertation (Manuscript), University of Köln.

Rusche, Georg e Otto Kirchheimer. 1939. Punishment and social structure. New York: Columbia University Press (reeditado em 1968 por Russell \& Russell, New York).

Schumpeter, Joseph A. 1963. History of Economic Analysis. New York: Oxford University Press.

Sellin, Thorsten. 1976. Slavery and the penal system. New York: Elsevier. Sherman-A. J.

Sellin, Thorsten. 1973. Island refuge: Britain and refugees from the Third Reich 1933-1939. London: Paul Elek.
Specht, M. eW. Eichler, eds. 1953. Leonard Nelson: Zum Gedächtnis. Frankfurt: Verlag Offentliches.

Stevens, Austin. 1975. The dispossessed: German refugees in Britain. London: Barrie \& Jenkins.

Struve, Walter. 1973. Elites against democracy. Princeton Princeton University Press.

\section{Dario Melossi}

Doutor em Sociologia pela Universidade da Califórnia Santa Bárbara, EUA. Professor da Universidade de Bologna, Bologna, Itália e da Universidade de Califórnia, Berkeley, EUA. 